\title{
JOURNAL.RU
}

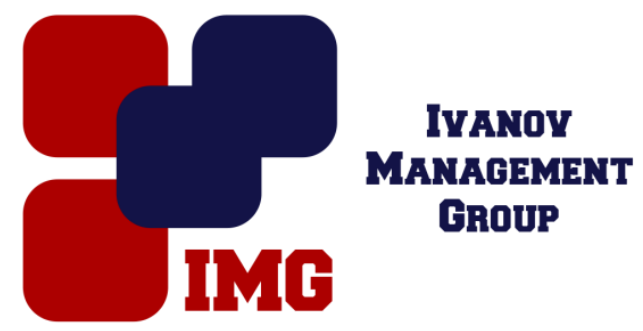

Кузнецова И.В.

ГУМРФ им. адм. С.О.Макарова Санкт-Петербург, Россия

doi: 10.18411/1j-31-07-2017-14

idsp 000001:1j-31-07-2017-14

\section{Интегрирование в языковом обучении на первом этапе морского образования}

\section{Аннотация}

Статья посвящена технологии интегрирования в языковом обучении, на основе которой на первом этапе морского образования можно построить курс обучения общепрофессиональной лексике морской технической сферы.

Ключевые слова: профессионально ориентированное обучение, общепрофессиональная лексика, интеграция, модульный курс.

\section{Abstract}

The article is devoted to the integration procedures in foreign language teaching on the basis of which, at the first stage of maritime education, it is possible to build a course in training of the general professional vocabulary of the maritime technical sphere.

Key words: profession-oriented training, general professional vocabulary, integration, modular course.

Процесс реформирования российского образования - явление закономерное в современном меняющемся мире. При этом осуществляется корректировка целей, пересмотр содержания обучения и поиск оптимальных педагогических технологий, что должно вести к реализации провозглашенных в отечественном образовании принципов демократизации, гуманизации, развития и вариативности. В сфере языкового обучения (в морском вузе) необходимо 
преодолевать рамки традиционного педагогического процесса, в котором до сих пор исключительно преподавателю предписывается роль «источника» информации, а учащемуся - роль пассивного «приемника» ограниченного количества в основном грамматических сведений. Таким образом, чтобы повысить эффективность изучения иностранного языка (английского) на первом, общепрофессиональном этапе морского образования (1-2 курсы), необходимо кардинально изменить организацию учебной деятельности.

При выборе конкретной технологии обучения оценивают следующие аспекты: результативность (достижение поставленной учебной цели каждым обучаемым); экономичность (усвоение большего объема учебного материала за единицу времени); эргономичность (обучение в обстановке сотрудничества, положительного эмоционального микроклимата); высокая мотивированность в изучении предмета (повышение интереса к занятиям, совершенствование личностных качеств обучаемого). Одной из технологий, обладающей данными характеристиками, является технология интеграции.

В.А. Сластенин отмечает важную проблему преодоления дегуманизации образования путем интеграции гуманитарного и естественно-научного знания, установления преемственности и междисциплинарных связей. Обучение в этой связи предстает не только как способ получения знания и формирования умений и навыков, но и как средство вооружения учащихся методами добывания новых знаний, самостоятельного приобретения умений и навыков [6, с. 189].

Общеизвестно, что языки - это средство хранения и передачи от поколения к поколению всех предметных, а не только лингвистических, знаний. Это создает основу их интеграции с другими учебными предметами. С помощью иностранного языка учащийся может присваивать знания из области истории, естествознания и техники, литературы и искусства, из всех сфер практической деятельности. Таким образом, иностранный язык, являясь предметом изучения, в то же время является средством познания и общения.

Интегративный подход к обучению, объединяющий различные методы и различные науки и противостоящий предметной дифференциации, способствует развитию креативности мышления обучаемых и системности их знаний, а также эффективности самого процесса обучения [7, с. 104].

Технология интеграции, в отличие от традиционного обучения, ограничивающего включаемые в учебную деятельность психические функции обучаемого, «предусматривает работу учащегося на уровне мышления 
(связанного с сомнением, постановкой вопросов, самостоятельными суждениями) и личности [2, с. 82].

Результатом процесса интеграции в образовании является создание нового курса, дисциплины, которые имеют комплексный характер, решают комбинированные задачи, формируют качественно новые знания обучаемых, развивают их творческий потенциал и являются важнейшим фактором оптимизации учебного процесса [1, с. 66].

В отличие от традиционных программ, интегрированные языковые курсы формируют полисистемное знание о мире. В интегрированных курсах более активно развиваются способности обучаемых к критическому мышлению, повышается мотивация обучения [3, с. 27].

Интегративные курсы строятся с учетом связи и характера взаимодействия иностранного языка с той или иной сферой жизнедеятельности, с приоритетными и актуальными проблемами сегодняшнего дня. В таких курсах иностранный язык является и средством, и целью обучения [3, с. 136].

Совмещение учебной информации с канвой социальной по своей сути профессионально-предметной деятельности приводит к усвоению студентами этой информации на уровне личностных смыслов, а не только закрепленных в науке значений $[2$, с. 79], то есть происходит развитие личностного потенциала обучаемых.

С позиций развития личности интеграция создает условия для:

- выхода на более высокий уровень осмысления;

- совершенствования индивидуально-личностного аппарата познания;

- развития свободы мышления;

- формирования способности креативности обучаемых [5, с. 452].

Профессионально ориентированное преподавание иностранного языка обусловлено характером межпредметных связей данного учебного предмета с предметами естественнонаучного, физико-математического и гуманитарного циклов. Способность иностранного языка хранить и передавать любую информацию дает возможность направлять содержание обучения на выделенный профиль [4, с. 173].

Морская техническая сфера уже представляет собой интеграцию естественнонаучных и технических знаний, а также опыта человека на протяжении её развития. При формировании предметной компетенции на общепрофессиональном этапе учебно-познавательная деятельность курсантов будет заключаться в освоении на английском языке информации, 
представляющей собой базовые элементы содержания разных дисциплин, описывающих морское дело, гидрографию, общетехническую сферу и составляющих морской технический контекст. Для этого необходимо овладение профессионально-ориентированной лексикой. Реализации этой цели будет способствовать интегрированный модульный курс введения в морскую тематику, в котором изучение общего английского языка (EGP - English for General Purposes) интегрируется с изучением содержания модуля (то есть раздела общепрофессиональной дисциплины).

Обучая лексике, и в том числе лексике общепрофессиональной, мы сталкиваемся с явлением интеграции в сфере самой лингвистики. История языка, лексикология, грамматика, стилистика, фонология, общее языкознание являются источником данных о словарном составе языка, вносят свой непосредственный вклад в процесс овладения лексикой, способствуют созданию у обучаемых системности знаний о языке.

Интегративная технология обучения дает возможность:

- систематизировать лексические знания;

- осуществлять взаимосвязанное обучение всем видам речевой деятельности, не изолируя формирование лексических умений и навыков;

- обеспечить индивидуальную траекторию личностного развития субъектов обучения в опоре на их когнитивные стратегии и стили;

- эффективно использовать различные средства обучения в сочетании традиционных и инновационных элементов [7, с. 89].

Посредством интегрированного курса можно обучить курсантов тем разделам знаний, которые при традиционной организации дисциплины английский язык не затрагиваются или бессистемно представлены единичными текстами. Организация учебного материала по модульному типу дает возможность нелинейной подачи информации, усвоения информации в автономном режиме, комбинирования занятий, построенных на работе с текстовым материалом и на работе с материалом видеофильмов. При этом достигаются важные цели обучения:

- развитие профессионального мышления;

- усиление мотивации к изучению английского языка за счет ввода интересной информации;

- приобретение значительного объема гуманитарных знаний; 
- формирование предметной компетенции в общепрофессиональной сфере;

- развитие способности к лингвистическому наблюдению;

- формирование лексических навыков и умений;

- развитие речемыслительных способностей;

- развитие навыков самообразования;

- всестороннее развитие личности на базе усвоенного профессионально- и культурно-значимого материала.

Интегрированный курс обладает очевидным преимуществом: обучаемые получают знания не только по иностранному языку, но и по нескольким предметам в комплексе, что формирует у них целостную картину мира во всех взаимосвязях; при этом повышается мотивация и познавательный интерес; снижается утомляемость за счет переключения внимания на разнообразные виды деятельности на занятии [1, с. 68].

Общий английский язык (EGP) в структуре интегрированного курса позволяет систематизировать и углубить языковые (фонетика, грамматика, лексика) знания и навыки, полученные в школе. Речевая и социокультурная компетенции как составляющие коммуникативной компетенции постепенно формируются при работе с материалом культурологической, общебытовой и общественно-политической тематики. Именно в рамках EGP возможно и целесообразно привлекать страноведческий материал (причем, курсанты отбирают его самостоятельно и представляют аудитории), новостной материал (выступление на занятии с текущими новостями, взятыми из англоязычных медиа источников).

На занятиях иностранного языка в рамках профессиональноориентированного интегрированного курса обучаемые отличаются активностью мышления, направленностью на решение мыслительных задач, стремлением к логическому упорядочению и систематизации, к поиску универсальных закономерностей, к самостоятельному нахождению способов обобщенной ориентировки в материале, теоретическим обобщениям [3, с. 102].

Выбор тематического содержания модулей соответствует общим программным требованиям обучения курсантов на первом этапе вузовского образования, а также обусловлен необходимостью полностью обновить учебный материал, который состоит из когда-то отксерокопированных текстов или берется из устаревших учебников. 
Интегрированный курс включает модули, построенные по одной схеме (предваряющее чтение текста (-ов) и последующий просмотр видео фильма), что позволяет следовать принципу повторяемости структуры учебного материала, принципу нарастания трудностей, принципу опоры на самостоятельную работу. По мере изучения материалов модулей и выполнения разнообразных заданий курсанты могут прогнозировать и оценивать свой прогресс в формировании навыков и умений, что способствует развитию самоконтроля и автономности обучаемых.

$* * *$

1. Вепрева Т.Б. Обучение профессионально-ориентированной иноязычной лексике студентов неязыковых специальностей на основе интегрированного курса: дис. ... канд. педагогич. наук. - СПб, 2012. - 198 с.

2. Вербицкий А.А. Личностный и компетентностный подходы в образовании: проблемы интеграции / А.А. Вербицкий, О.Г. Ларионова. - М.: Логос, 2015. - 336 с.

3. Милованова Л.А. Профильно-ориентированное обучение иностранным языкам (английский язык, старшая ступень средней общеобразовательной школы): Монография. - Волгоград: Изд-во ВГПУ «Перемена», 2006. - 347 с.

4. Пименова Г.В. Опыт формирования языковой компетенции у студентов неязыковых вузов // Проблемы современной филологии и лингводидактики: Сборник научных трудов. Вып. 5. - СПб.: Изд-во РГПУ им. А.И. Герцена, 2012. - 211 с.

5. Селевко Г.К. Энциклопедия образовательных технологий: В 2 т. Т.1. М.: НИИ школьных технологий, 2006. - 816 с.

6. Сластенин В.А. Психология и педагогика : учеб. пособие для студ. высш. учеб. заведений / В.А. Сластенин, В.П. Каширин. - 6-е изд., стереотип. - М. : Издательский центр «Академия», 2007. - 480 с.

7. Стрелкова С.Ю. Интегративное обучение иноязычной грамматике: От предложения к дискурсу. - М.: Книжный дом «ЛИБРОКОМ», 2012. - 184 с. 